\title{
PEMBINAAN MODEL GRAFIK MULTIMEDIA INTERAKTIF UNTUK PENGAJARAN PENJODOH BILANGAN BAGI KANAK-KANAK TAHUN DUA
}

\author{
The Construction of Interactive Multimedia Graphic Model for Second Year's Numbering \\ Teaching for Children
}

Adenan Ayob

Fakulti Bahasa dan Komunikasi, Universiti Pendidikan Sultan Idris, 35900 Tanjong Malim, Perak

adenan@fbk.upsi.edu.my

\begin{abstract}
ABSTRAK
Kajian ini bertujuan membina model grafik multimedia interaktif untuk pengajaran penjodoh bilangan. Kaedah pembinaan model grafik multimedia interaktif berasaskan reka bentuk kajian kualitatif digunakan dalam penyelidikan ini. Proses pembinaan model grafik ini dilakukan dengan diasaskan kepada ADDIE oleh Rosset (1987). Terdapat lima fasa yang dilakukan sepanjang pembinaan model ini iaitu analisis, reka bentuk, pembangunan, pelaksanaan dan penilaian. Analisis dibuat terhadap kanak-kanak tahun dua, persekitaran, dan masalah pembelajaran. Model ini telah diuji penggunaannya dengan berdasarkan penilaian pakar yang menyentuh tentang kesahan kandungan dan konstruk. Dari segi implikasi, model ini dapat memanfaatkan guru dalam pengajaran penjodoh bilangan kerana ciri-cirinya adalah terarah kepada penjanaan minda kanak-kanak untuk penjodoh bilangan. Model ini dicadangkan untuk digunakan oleh guru Bahasa Melayu tahun dua.
\end{abstract}

Kata Kunci: pembinaan model grafik, multimedia interaktif, penjodoh bilangan, kanak-kanak tahun dua

\begin{abstract}
The purpose of this study is to build an interactive multimedia graphic model for the teaching of classifiers. Methods of constructing interactive multimedia graphic model based on qualitative research design are used in this research. The process of constructing this graphic model was based on ADDIE by Rosset (1987). There are five phases that are carried out throughout the construction of this model; analysis, design, development, implementation and evaluation. An analysis was made on two-year children, the environment, and learning problems. This model has been tested on its use based on an expert assessment that dealt with validity of content and constructs. In terms of implication, this model can leverage on the number of teachers in the teaching of classifiers because their characteristics are directed towards constructive thinking that based on graphic. This model is intended to be used by standard two Malay Language teachers.
\end{abstract}

Keywords: build an interactive multimedia graphic model, interactive multimedia, classifiers, two-year children

\section{PENGENALAN}

\section{Latar Belakang Kajian}

Trend penggunaan bahan pengajaran semasa telah berubah ke arah kemajuan dalam inovasi. Malaysia pada masa ini merupakan sebuah negara yang sedang membangun pesat dalam inovasi teknologi maklumat. Perkembangan bidang teknologi maklumat telah mengembangkan pelbagai bidang penting di Malaysia. Bidang pendidikan turut mengalami perkembangannya. Seiring 
dengan perkembangan dalam bidang pendidikan, transformasi pengajaran telah memberikan penekanan terhadap bidang pendidikan (Adenan Ayob \& Khairuddin Mohammad, 2012).

Selaras dengan perkembangan bidang pendidikan, guru bukan sahaja perlu menjalankan tanggungjawab sebagai pendidik, tetapi guru perlu mengamalkan inovasi untuk mendidik murid. Oleh hal yang demikian, guru perlu mengetahui dan mengadaptasikan aspek pedagogi semasa proses pengajaran (Adenan Ayob \& Khairuddin Mohammad, 2012). Dalam konteks yang lain inovasi adalah untuk memperagakan sains dan seni mengajar (Norasiah Abdullah et al., 2011). Pedagogi dalam pengajaran bahasa melibatkkan kajian ini secara umumnya adalah tentang akomodasi, asimilasi, dan equilibrium untuk proses pengajaran dan interaksi antara murid dengan bahan (Kamarudin $\mathrm{Hj}$. Husin et al., 2014).

Pedagogi dalam bahasa juga merujuk kepada penggunaan yang tepat dalam strategi, pendekatan, kaedah dan teknik mengajar. Oleh hal yang demikian, guru perlu berinovasi dalam konteks pengajaran berasaskan teknologi maklumat untuk memastikan murid dapat menerima pengetahuan dengan berkesan. Pengintegrasian aspek pengetahuan dan pedagogi adalah seiring dengan hasrat Falsafah Pendidikan Negara (Ahmad Rizal Madar, 2009).

\section{Pernyataan Masalah}

Menurut Asmah Haji Omar (2014) murid pada masa ini tidak begitu teliti dalam penggunaan bahasa terutamanya dari segi pemilihan penjodoh bilangan. Contohnya, buah digunakan sesuka hati. Dalam contoh yang lain seperti sebuah kata, sebuah ayat, dan sebuah program. Penggunaan kata yang seperti ini adalah tidak gramatis, selain tidak menyelami jiwa dan penghayatan sistem Bahasa Melayu. Selain itu, terdapat kajian yang dijalankan yang berkaitan dengan model untuk membantu pengajaran guru. Kajian lain yang wujud juga mendapati bahawa masih terdapat guru Bahasa Melayu yang tidak memanfaatkan model bantu pengajaran yang dianggap masih terikat dengan tradisi lama atau konvensional yang lebih berpusatkan guru, selain tidak berpaksikan sesuatu model acuan yang sesuai (Mohd Paris Saleh, 2016).

Kajian oleh Ab. Halim Tamuri et al. (2010) menunjukkan bahawa masih ramai guru lazim membina model yang konvensional di dalam bilik darjah. Menurut Ab. Halim Tamuri et al. (2010) juga, pembinaan model yang konvensional menjadikan guru sudah terlazim tanpa memikirkan rangsangan untuk murid berfikir dalam penjodoh bilangan.

Justeru, kajian ini cuba membina model grafik multimedia interaktif untuk pengajaran penjodoh bilangan tahun dua. Pembinaan model diasaskan kepada ADDIE oleh Rosset (1987).

\section{OBJEKTIF KAJIAN}

Daripada pernyataan masalah, objektif kajian telah digubal. Objektif kajian bagi penyelidikan ini adalah seperti yang berikut:

Membina model grafik multimedia interaktif untuk pengajaran penjodoh bilangan bagi kanakkanak tahun dua dengan berasaskan pandangan Rosset (1987). 


\section{Soalan Kajian}

Daripada objektif kajian pula, soalan kajian turut digubal. Soalan kajian bagi penyelidikan ini adalah seperti yang di bawah:

Bagaimanakah model grafik multimedia interaktif untuk pengajaran penjodoh bilangan bagi kanak-kanak tahun dua dibina dengan berasaskan pandangan Rosset (1987)?

\section{KEPENTINGAN KAJIAN}

Kajian ini berkepentingan dalam membantu guru semasa melakukan sesi pengajaran dan pembelajaran di dalam bilik darjah. Selain itu, kajian ini mampu dijadikan panduan kepada guru tentang model inovasi untuk mengajar penjodoh bilangan. Kajian ini juga dapat memberikan maklumat kepada guru untuk mencuba kaedah pembinaan model grafik multimedia interaktif yang tersusun, berorganisasi, dan sistematik.

Pembinaan model grafik multimedia interaktif juga dapat memudahkan proses dan prinsip pengajaran penjodoh bilangan di dalam bilik darjah. Hal ini demikian kerana isi pengajaran lebih menarik tumpuan atau fokus murid, di samping dapat menjadikan sesuatu langkah pengajaran bagi penjodoh bilangan lebih berpaksikan penjanaan minda, termasuk bersesuaian dengan objektif pengajaran yang hendak dicapai.

\section{Definisi Operasional}

\section{i. Model Grafik}

Menurut Kamus Dewan Edisi Keempat (2005), model membawa maksud sesuatu yang dapat dijadikan contoh untuk ditiru atau diteladani. Perkataan grafik pula membawa maksud maklumat atau paparan yang terdiri daripada lukisan, simbol, gambar rajah dan sebagainya untuk menyatakan atau menyampaikan idea. Grafik multimedia interaktif pula membawa maksud bahan berasaskan komputer untuk mencipta, mengolah, memapar, mencetak imej. Oleh hal yang demikian, model grafik merupakan suatu model yang menggunakan sejumlah garis, simbol atau bentuk.

Selain itu, Norasiah Abdullah et al. (2011) berpendapat bahawa grafik multimedia interaktif ialah komponen geometri yang dihasilkan menerusi kombinasi antara garisan, bulatan, kotak, bayangan dan warna yang dibina dengan menggunakan paparan imej. Grafik juga sangat berkesan untuk menyampaikan maksud menerusi penerangan dalam persembahan interaktif. Hal ini demikian kerana kombinasi pelbagai grafik interaktif dapat menyampaikan maklumat dengan lebih jelas, tepat, dan berkesan. Norasiah Abdullah et al. (2011) turut membahagikan grafik multimedia interaktif kepada dua, iaitu grafik bitmap dan vektor.

Pembinaan model grafik ini dioperasikan menerusi proses ADDIE yang diperkenalkan oleh Rosset (1987) dengan membabitkan lima fasa iaitu analisis, reka bentuk, pembangunan, pelaksanaan dan penilaian. Fasa analisis dilakukan untuk mengenal pasti masalah yang ingin diselesaikan. Analisis dijalankan terhadap kanak-kanak tahun dua. Analisis ini juga dilakukan terhadap persekitaran pembelajaran seperti halangan yang wujud semasa pembelajaran. Hal ini 
bagi membolehkan matlamat atau objektif pengajaran mudah tercapai hasil daripada paparan grafik interaktif yang bermakna (Arihasnida Ariffin et al., 2010).

Seterusnya, diikuti dengan fasa reka bentuk. Fasa reka bentuk ini bertujuan menjelaskan pandangan keseluruhan tentang rupa bentuk, struktur, pendekatan teori, jenis media dan teknologi yang digunakan. Fasa ini penting untuk merancang strategi dalam pengajaran serta menggariskan cara mencapai objektif pengajaran. Guru menggunakan model grafik multimedia interaktif sebagai panduan pengajaran yang lancar (Ahmad Rizal Madar, 2009).

Fasa seterusnya adalah pembangunan. Tujuan fasa ini adalah untuk menghasilkan rancangan pengajaran dan model secara langsung. Fasa ini melibatkan proses pembinaan model grafik multimedia interaktif untuk pengajaran penjodoh bilangan. Model ini telah diuji kesahannya oleh seorang pakar pedagogi dan seorang teknologi maklumat.

Pada fasa pelaksanaan pula, bahan pengajaran yang disediakan, iaitu model grafik multimedia digunakan oleh guru dalam pengajaran penjodoh bilangan. Di peringkat ini, penjodoh bilangan diajarkan menerusi rancangan pengajaran harian. Fokus adalah kepada langkah-langkah dalam penjanaan berfikir untuk murid mengecam dan memperoleh pengetahuan tentang sesuatu penjodoh bilangan.

Dalam konteks penilaian, model telah diuji oleh pengguna guru. Bahan dimurnikan dengan berdasarkan kitaran perancangan hingga penilaian. Fasa penilaian terbahagi kepada dua bahagian iaitu penilaian formatif dan penilaian sumatif. Dalam fasa ini, model dinilai dari segi tahap pencapaian objektif pembelajaran yang telah ditetapkan dalam rancangan pengajaran.

\section{ii. Multimedia Interaktif}

Menurut Kamus Dewan Edisi Keempat (2005), mutimedia adalah tentang penggunaan pelbagai jenis media seperti slaid dan televisyen, terutamanya dalam persembahan mengajar. Multimedia merupakan sistem komputer yang memapar atau menggabungkan elemen audio, animasi, grafik dan teks. Interaktif pula adalah saling bertindak serta berhubung antara satu sama lain yang membolehkan pengaliran maklumat secara dua hala berlaku, berterusan antara komputer dengan pengguna atau antara pengguna dengan pengguna menerusi komputer.

\section{iii. Pengajaran Penjodoh Bilangan}

Menurut Kamus Dewan Edisi Keempat (2005), pengajaran bermaksud perihal mengajar dan segala sesuatu yang berkaitan dengan mengajar. Contoh adalah cara atau sistem mengajar dan aspek yang dipentingkan.

Menurut Kamus Dewan Edisi Keempat (2005) juga, perkataan penjodoh bermaksud pemadan, pasangan atau lawan. Perkataan bilangan pula membawa maksud jumlah barang, lingkungan atau golongan nasib yang sudah tertentu dan waktu yang sudah tertentu. Oleh hal yang demikian, menurut Kamus Dewan Edisi Keempat (2005), penjodoh bilangan bermaksud perkataan yang digunakan berpasangan dengan nama apabila menunjukkan bilangan seperti ekor yang menunjukkan binatang dan biji yang menunjukkan buah-buahan. Penjodoh bilangan merupakan kata yang digunakan bersama-sama dengan kata bilangan. Penjodoh bilangan juga digunakan untuk menentukan sesuatu benda berpandukan bentuk, rupa, saiz, dan sebagainya serta turut digunakan sebelum sesuatu kata nama yang menunjukkan jumlah atau bilangan (Kamus Dewan Edisi Keempat, 2005). 


\section{SOROTAN LITERATUR}

\section{i. Pengajaran Berbantukan Komputer}

Penjodoh bilangan termaktub bawah aspek sistem bahasa dalam sukatan pelajaran Bahasa Melayu sekolah rendah. Dari segi kajian, masih ramai murid sekolah rendah, terutamanya dalam tahun dua yang belum menguasai penjodoh bilangan (Adenan Ayob \& Khairuddin Mohammad, 2012). Kelemahan dalam penjodoh bilangan telah menjejaskan komunikasi lisan dan penulisan murid, khusus dalam aspek tatabahasa (Kamarudin $\mathrm{Hj}$. Husin et al., 2014).

Pengajaran berbantukan bahan berasaskan komputer merupakan salah satu cara untuk melahirkan generasi yang kreatif, inovatif, kritis dan berwawasan selaras dengan hasrat kerajaan untuk mencapai hasrat Falsafah Pendidikan Negara. Perkara ini menjadi asas kepada pembentukan kurikulum pendidikan Malaysia yang menjurus kepada transformasi teknologi maklumat. Pengajaran berbantukan komputer dan teknologi maklumat merupakan salah satu proses yang mampu membantu menjayakan strategi berpusatkan murid dan bahan (Norasiah Abdullah et al., 2011).

Perancangan yang teliti diperlukan dalam menghasilkan bahan berasaskan komputer yang sesuai dan berkesan menerusi teknologi multimedia dapat memberikan peluang kepada kanakkanak untuk berinteraksi dengan bahan. Guru memainkan peranan yang penting dalam penyebaran penggunaan komputer. Tujuannya untuk memudahkan kanak-kanak berinteraksi dengan komputer dalam susunan pelajaran yang telah diprogramkan oleh guru, sama ada dalam bentuk nota, tutorial, latihan ataupun simulasi (Norasiah Abdullah et al., 2011).

\section{ii. Model Pengajaran}

Model pembelajaran memiliki makna yang lebih luas daripada sesuatu prosedur. Model pembelajaran mencakupi pendekatan pengajaran yang menyeluruh. Contohnya model pengajaran berdasarkan masalah yang melibatkan kumpulan kecil kanak-kanak untuk bekerjasama dan berkolaborasi. Model juga dapat berfungsi sebagai alat komunikasi yang penting. Model pembelajaran diklasifikasikan dengan berdasarkan tujuan pengajaran. Menurut Norasiah Abdullah et al. (2011), penggunaan sesuatu model pengajaran tertentu membolehkan guru mencapai tahap tertentu. Sesuatu model pengajaran mempunyai empat ciri khusus, iaitu:

i. Rasional teoritik yang logik disusun oleh pengkaji.

ii. Landasan pemikiran tentang cara murid belajar.

iii. Tingkah laku mengajar yang diperlukan supaya model dapat digunakan dengan betul. iv. Lingkungan belajar yang diperlukan supaya tujuan pembelajaran dapat dicapai.

\section{METODOLOGI}

\section{i. Reka Bentuk Kajian}

Reka bentuk kajian kualitatif digunakan dalam penyelidikan ini. Maklumat yang berkaitan dengan pembinaan model grafik multimedia interaktif untuk pengajaran penjodoh bilangan dijalinkan dalam kaedah kajian. 


\section{ii. Kaedah Kajian}

Kaedah pembinaan model reka bentuk instruksional grafik multimedia interaktif digunakan dalam penyelidikan ini. Kaedah ini dibina untuk memberi kemudahan kepada guru untuk mengajar terutamanya pengajaran penjodoh bilangan. Kaedah ini dibina dengan menggunakan bahan grafik multimedia interaktif. Penggunaan grafik dalam pengajaran penjodoh bilangan bertujuan memberikan kemudahan kepada guru semasa mengajar kanak-kanak lebih jelas apabila wujudnya simbol dinamik.

\section{iv. Proses Pembinaan Model}

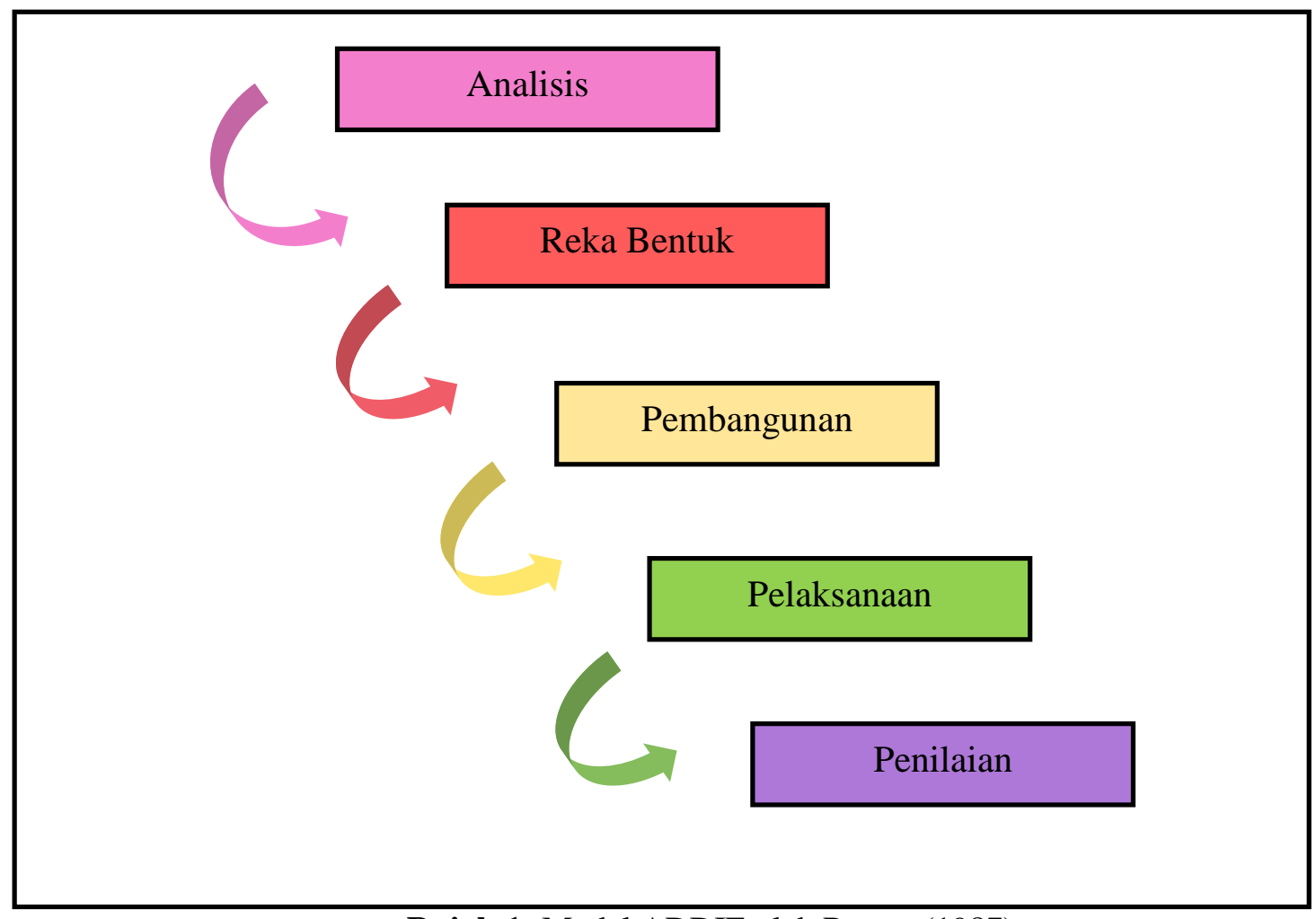

Rajah 1: Model ADDIE oleh Rosset (1987)

Rajah 1 di atas merupakan proses pembinaan model grafik yang diacuankan daripada model ADDIE oleh Rosset (1987). Model ADDIE ini digunakan kerana bersesuaian dengan aras dan tahap murid serta kehendak Sukatan Pelajaran Bahasa Melayu Tahun Dua. Model ADDIE ini juga sesuai dari segi kriteria kemahiran berfikir seperti penaakulan kreatif dan kritis. Terdapat lima fasa dalam model ADDIE iaitu analisis, reka bentuk, pembangunan, pelaksanaan dan penilaian. 


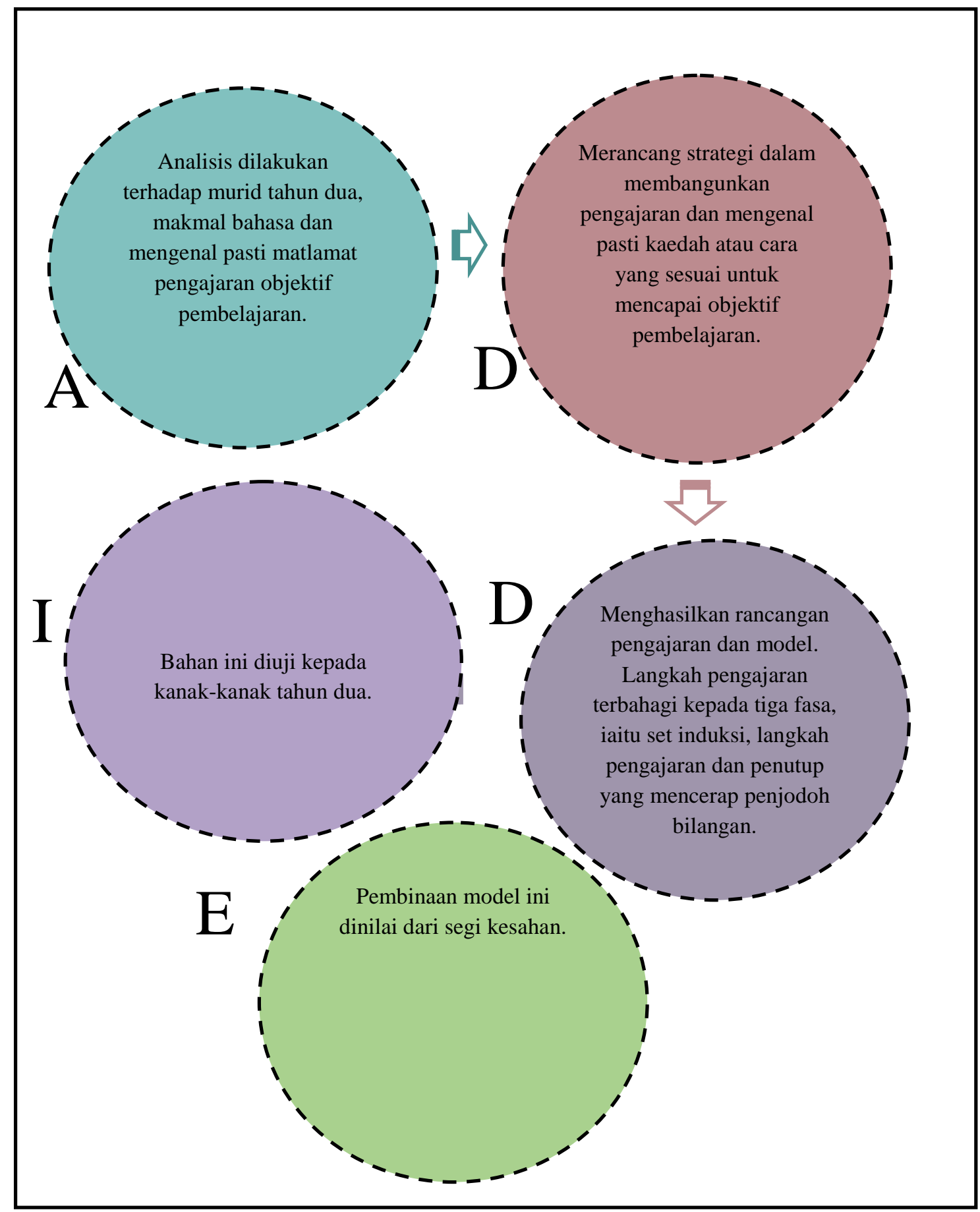

Rajah 2: Proses pembinaan Model Grafik Multimedia Interaktif untuk pengajaran penjodoh bilangan tahun dua berdasarkan Model ADDIE oleh Rosset (1987)

\section{v. Proses Pembinaan Model Grafik Multimedia Interaktif}

Pembinaan model grafik multimedia interaktif terbahagi kepada lima fasa. Fasa berkenaan ialah analisis, reka bentuk, pembangunan, pelaksanaan dan penilaian. 


\section{Analisis}

Fasa analisis bertujuan mengenal pasti masalah yang ingin diselesaikan. Analisis ini dilakukan terhadap kanak-kanak dua. Analisis dilakukan terhadap persekitaran pembelajaran kanak-kanak, iaitu di makmal bahasa. Hal ini demikian kerana makmal bahasa adalah lengkap dengan prasarana komputer.

Bagi kajian ini, pengkaji menggunakan strategi pengajaran yang berpusatkan murid, bahan dan masalah. Objektif pembelajaran penjodoh bilangan ditentukan. Objektif pembelajaran adalah untuk:

i. Mengenal pasti penjodoh bilangan yang sesuai dengan objek grafik yang diberikan.

ii. Menulis tiga ayat dengan menggunakan grafik dalam penjodoh bilangan secara gramatis.

Pembinaan model grafik dalam pengajaran penjodoh bilangan bertujuan melihat tindak balas kanak-kanak setelah diberikan rangsangan. Rangsangan yang digunakan oleh pengkaji ialah dengan menggunakan grafik multimedia interaktif dalam pengajaran penjodoh bilangan. Daripada rangsangan yang diberikan kanak-kanak dapat mempersembahkan penjodoh bilangan yang telah dipelajari dalam aktiviti pembelajaran.

\section{Reka Bentuk}

Setelah fasa analisis selesai, pengkaji akan melaksanakan fasa reka bentuk. Fasa ini merupakan fasa yang berfokus kepada perancangan strategi untuk mencapai objektif pembelajaran. Papan cerita juga dibina untuk memudahkan proses reka bentuk instruksional grafik mutimedia interaktif untuk pengajaran penjodoh bilangan tahun dua.

Reka bentuk memberikan penerangan mengenai maksud penjodoh bilangan. Bagi contoh penjodoh bilangan, diletakkan grafik sepasang burung hantu. Hal ini demikian untuk membawa maksud pasangan. Justeru, kanak-kanak dapat menentukan penjodoh bilangan yang bermaksud pasangan berdasarkan grafik berkaitan.

Bagi perkataan bilangan pula, telah disenaraikan nombor iaitu satu, dua dan tiga. Daripada nombor-nombor tersebut, kanak-kanak dapat mengetahui perkataan bilangan boleh dikaitkan dengan bilangan. Oleh hal yang demikian, secara tidak langsung kanak-kanak dapat menentukan penjodoh bilangan yang merupakan kaitan antara pasangan dalam bentuk kuantiti.

Seterusnya, dipaparkan grafik sehelai baju. Daripada grafik tersebut, kanak-kanak dapat melihat ciri-ciri yang wujud, iaitu nipis dan mempunyai permukaan yang lebar. Daripada ciriciri tersebut, kanak-kanak dapat mengetahui sesuatu objek yang mempunyai permukaan yang lebar dan nipis. Penjodoh bilangan yang sesuai ialah helai. Kanak-kanak juga akan mengetahui bahawa penjodoh bilangan bagi baju ialah helai. Antara grafik lain kertas, kain, tuala, rambut, dan rumput. Berikut merupakan antara contoh ayat yang boleh dibina oleh kanak-kanak dengan menggunakan penjodoh bilangan helai. Antara ayat ialah:

a. Ibu telah membelikan abang sehelai baju baharu sebagai hadiah ulang tahun kelahiran.

b. Cikgu telah mengedarkan sehelai kertas kepada setiap kanak-kanak untuk dijadikan kertas contengan. 


\section{Pembangunan}

Fasa pembangunan bertujuan membina sistem sebenar dengan menggunakan elemen grafik dan teknologi yang terpilih berdasarkan keperluan. Fasa ini juga menghasilkan rancangan pengajaran dan bahan pengajaran. Langkah pengajaran terbahagi kepada tiga fasa iaitu set induksi, langkah pengajaran dan penutup. Berikut merupakan pembinaan model reka bentuk instruktional grafik multimedia interaktif untuk pengajaran penjodoh bilangan.

\section{Pelaksanaan}

Fasa pelaksanaan, bahan pengajaran yang disediakan, iaitu model grafik multimedia interaktif akan digunakan dalam proses pengajaran dan pembelajaran yang sebenar, iaitu semasa guru mengajar penjodoh bilangan kepada kanak-kanak. Model yang dibina diuji kepada murid dan dibaiki sekiranya terdapat masalah sebelum diserahkan sepenuhnya kepada guru untuk dilaksanakan semasa sesi pengajaran. Bahan ini diuji kepada murid tahun dua.

\section{Penilaian}

Fasa yang terakhir dalam pembinaan model reka bentuk instruksional grafik multimedia interaktif ini ialah penilaian. Bagi fasa ini, pembinaan model ini hanya akan dinilai dari segi kesahan kandungan dan konstruk.

\section{PERBINCANGAN}

Kajian tentang pembinaan model telah mevariasikan bahan dengan berpandukan proses pengajaran dengan lebih berkesan. Terdapat beberapa kajian yang melibatkan pembinaan model ini. Antaranya ialah kajian yang dilakukan oleh Mohd Paris Saleh (2016). Beliau dan rakanrakan telah melakukan kajian tentang reka bentuk perisian multimedia membaca-faham berasaskan gambaran grafik bagi kanak-kanak prasekolah.

Hasil daripada kajian tersebut dapat mewujudkan kemahiran menaakul bahan bacaan dalam kalangan kanak-kanak prasekolah, di samping dapat meningkatkan bilangan peratus kanakkanak yang berupaya membaca dan faham semasa peringkat prasekolah. Sejajar dengan kajian ini, penyelidikan oleh Mohd Paris Saleh (2016) turut memberikan keutamaan kepada grafik yang dihasilkan untuk penjanaan minda kanak-kanak.

Berikutnya, Arihasnida Ariffin et. al (2010) telah menjalankan satu kajian yang bertujuan mmembangunkan perisian lukisan dengan menggunakan grafik bitmap. Model tersebut dapat menerapkan pengajaran secara terancang. Selaras dengan hasil kajian Arihasnida Ariffin et. al (2010) juga, bahan grafik membolehkan kanak-kanak untuk menguasai topik pelajaran dengan lebih mantap.

Mohd Paris Saleh (2016) juga telah membangunkan model grafik berasaskan teknik inkuiri. Kajian ini menggunakan reka bentuk pembinaan model yang telah dijana oleh Richard Culcatta (2013). Aktiviti yang dijalankan dapat memudahkan pentaksiran. Selaras dengan dapatan Richard Culcatta (2013), terdapat persamaan dengan kajian ini, iaitu guru dapat memberikan pentaksiran yang tepat untuk penskoran atau pemarkahan bagi sesuatu penjodoh bilangan yang diajarkan. 
Menurut Richard Culcatta (2013) juga, model yang berorientasikan sistem adalah memenuhi fahaman behavioris. Hal ini bermaksud model ADDIE yang digunakan oleh dalam kajian ini adalah bertujuan meninjau tindak balas kanak-kanak terhadap topik penjodoh bilangan dengan berasaskan grafik multimedia interaktif.

\section{PENUTUP}

Penggunaan model grafik multimedia interaktif mampu meningkatkan pengetahuan kanakkanak dalam penjodoh bilangan. Oleh hal yang demikian, guru perlu lebih kreatif, kritis, dan inovatif untuk memastikan kanak-kanak berpengetahuan lebih luas dalam topik penjodoh bilangan yang diajarkan. Hasil pembinaan model grafik multimedia interaktif ini juga adalah bersesuaian dengan unsur behavioris, kognitif, dan interaksionalis untuk membolehkan kanakkanak menentukan sesuatu penjodoh bilangan dengan tepat dan berkesan.

\section{RUJUKAN}

Ab. Halim Tamuri et al. (2010). Bahan pengajaran Pendidikan Islam secara konvensional dan inovasi. Bangi: Universiti Kebangsaan Malaysia Press.

Adenan Ayob \& Khairuddin Mohammad. (2012). Kaedah pengajaran Bahasa Melayu. Shah Alam: Oxford Fajar Sdn. Bhd.

Ahmad Rizal Madar (2009). Model bagi keberkesanan grafik dalam kalangan murid berbeza gaya kognitif dan kebolehan visualisasi spatial. Diakses pada 25 April 2017 daripada http://eprints.utm.my/16967/4/.

Arihasnida Ariffin et al. (2010). Reka bentuk pembinaan model pengajaran Sains tingkatan empat. Diakses pada 3 Jun 2017 daripada http://eprints.uthm.edu.my/3191/1/93.

Asmah Haji Omar. (2014). Nahu Melayu mutakhir edisi kelima. Kuala Lumpur: Dewan Bahasa dan Pustaka.

Kamarudin Hj. Husin et al. (2014). Pedagogi asas pendidikan edisi baharu. Tanjong Malim, Perak: Emeritus Publications.

Kamus Dewan Edisi Keempat. (2005). Kuala Lumpur: Dewan Bahasa dan Pustaka.

Mohd Paris Saleh. (2016). Model pengajaran berasaskan teknik inkuiri. Diakses pada 7 Jun 2016 daripada http://studentsrepo.um.edu.my/.

Norasiah Abdullah et al. (2011). Teknologi maklumat dan komunikasi. Selangor: Penerbitan Multimedia Sdn. Bhd.

Richard Culcatta. (2013). Model ADDIE. Diakses pada 1 Jun 2017 daripada http://www.instructionaldesign.org/models/addie.htm

Rossett, A. (1987). Training needs assessment. Englewood Cliffs, NJ: Educational Technology Publications. 